\title{
Çalışanların İş Yaşam Kalitesinin Bağlamsal ve Görev Performansı Üzerindeki Etkisine Yönelik Bir Araştırma
}

\author{
Mutlu Tokmak
}

\section{Özet}

İş yaşam kalitesi çalışanların iş ortamı, çalışma şartları ve işyerinden sağlanan hizmetler bakımından çalışanların memnuniyet algılarını ifade etmektedir. İş performansı ise, bağlamsal performans ve görev performansı açısından çalışanların verimliliklerini ve etkinliklerini ortaya koymalarını belirtmektedir. Bu çalışmada, işgörenlerin iş yaşam kalitesi algılarının, bağlamsal performans ve görev performansı üzerindeki etkilerini ortaya koymaktır. Ayrıca iş yaşam kalitesi alt boyutları olan iş ortamı, çalışma koşulları ve sağlanan hizmetler ile iş performansı alt boyutları olan bağlamsal performans ve görev performansı arasındaki ilişkilerin incelenmesi de araştırma amaçları arasında yer almaktadır. Çalışmada beklenen amaçları gerçekleştirmek içim alan araştırması yapılmıştır. Alan araştırmasında veri toplama tekniği olarak anket yöntemi uygulanmıştır. Bursa ili Karacabey ilçesinde görev yapan 158 kamu çalışanı araştırmaya katılmıştır. Araştırmada belirlenen hipotezleri test etmek amacıyla korelâsyon analizi ile basit ve çoklu doğrusal regresyon analizi gerçekleştirilmiştir. Analiz neticesinde istatistiksel olarak anlamlı sonuçlar elde edilmiştir. Korelâsyon analizi sonucunda, iş yaşam kalitesi ile genel iş performansı, bağlamsal performans ve görev performansı arasında orta düzeyde ve pozitif yönlü ilişki olduğu tespit edilmiştir. Çalışanların genel iş performansının, iş yaşam kalitesinden etkilenme düzeyi düşük seviyede, bağlamsal ve görev performansının iş yaşam kalitesi alt boyutlarından etkilenme düzeyi ise orta seviyededir.
Anahtar Kelimeler

İş Yaşam Kalitesi

İș Performansı

Bağlamsal Performans

Görev Performansı

Makale Hakkında

Geliş Tarihi: 06.08.2019

Kabul Tarihi: 10.05.2021

Doi: 10.18026/cbayarsos.602907

\section{A Study on The Effect of Employees Quality of Work Life on Contextual and Task Performance}

\begin{abstract}
The quality of work life expresses the employees' perception of satisfaction in terms of work environment, working conditions and services provided from the workplace. Job performance, in terms of contextual performance and task performance, indicates that employees demonstrate their efficiency and effectiveness. In this study, it is aimed to reveal the effects of employees' perception of quality of work life on contextual performance and task performance. In addition, the study aims to investigate the relationship between job quality, work environment, working conditions and services provided, and job performance sub-dimensions, contextual performance and task performance. In the study, field research was conducted to realize the expected objectives. In the field research, questionnaire method was applied as data collection technique. 158 public employees in Karacabey district of Bursa participated in the study In order to test the hypotheses determined in the study, correlation analysis and simple and multiple linear regression analysis were performed. As a result of the analysis, statistically significant results were obtained. As a result of the correlation analysis, it was determined that there is a moderate and positive relationship between work life quality and general job performance, contextual performance and task performance. The level of influence of the general work performance of the employees from the quality of work life is low; the level of being affected by the contextual and task performance sub-dimensions of the quality of work life is moderate
\end{abstract}

Keywords

Quality of Work Life

Job Performance

Contextual Performance

Task Performance

About Article

Received: 06.08.2019

Accepted: 10.05.2021

Doi: $10.18026 /$ cbayarsos.602907

a Doç. Dr. J. Bnb. , Jandarma ve Sahil Güvenlik Akademisi, Jandarma ve Sahil Güvenlik Fakültesi, Sosyal Bilimler Bölümü, 06000, Ankara / Türkiye, mutlu-tokmak@hotmail.com, ORCID ID: orcid.org/0000-0002-7428-1322 


\section{Giriş}

Örgütlerin rekabet ortamında başarılı olmasında çalışanlarının performans düzeylerinin etkisi büyüktür. Nitelikli personele sahip olan işletmeler, çalışanlarının yeteneklerini gösterebilecekleri uygun çalışma ortamı oluşturabildiklerinde onlardan en yüksek verimi elde etme imkânı bulacaklardır. Çalışanların iş yaşamında mutlu, huzurlu ve verimli olabilmeleri için iş yaşamına ilişkin görüşlerinin olumlu olması gerekmektedir. Çalışanların nitelikleri ne kadar yüksek olursa olsun, bu niteliklerini sergileyebilecekleri çalışma ortamının sağlanmadığı durumlarda verimli olmalarını beklemek haksızlık olur.

Çalışanlarından en üst seviyede verim almak isteyen örgütlerin öncelikle personeli için bu yeteneklerini gösterebilecekleri uygun bir çalışma ortamı sağlamaları gerekmektedir. Bunun için çalışanların iş yaşam kalitelerinin yükseltilmesi gerekmektedir.

İş yaşam kalitesi kavramı 1970'li yılların ortalarında geliştirilmiş, insanların işe olan tepkileri, iş tatmini ve mental olarak kendilerini iyi hissetmeleri olarak tanımlanmıştır. İş yaşam kalitesi başlangıçta, çalışanların iş deneyimini ve kişisel ihtiyaçlarını iyileştirmeye odaklanmış, sonrasında iş zenginleştirme, kendi kendini idare eden takımlar, iş kalitesinin artırılmasına yönelik teknikler ve yaklaşımlar üzerine odaklanmıştır (Davis \& Cherns, 1975; Davis, 1977).

Örgüt içerisinde iş yaşam kalitesi yüksek olan, bulundukları iş ortamından, çalışma koşullarından ve işletme tarafından sağlanan hizmetlerden memnun olan çalışanların performanslarının da yüksek olması beklenmektedir.

$\mathrm{Bu}$ çalışmada, işgörenlerin iş yaşam kalitesine ilişkin algıları ile iş performansı ve alt boyutları olan bağlamsal ve görev performansı arasındaki ilişkileri ortaya koymak amaçlanmaktadır. Ayrıca iş yaşam kalitesine ilişkin algıların, çalışanların bağlamsal performansı ve görev performansı üzerindeki etkileri de incelenmektedir. Bu alanda ilgili literatür incelenerek geçmiş araştırmalar değerlendirilmiş, alan araştırması ile elde edilen verilerin analiz sonuçları ile karşılaştırmalı olarak aktarılmaya çalışılmıştır.

\section{Kavramsal Çerçeve}

\section{İş Yaşam Kalitesi}

İş yaşam kalitesi kavramı ile ilgili Fransızlar "çalışma koşullarının iyileştirilmesi", Almanlar "işin insancıllaştırılması", Doğu Avrupalılar ise "çalışanın korunması" ifadeleri ile özdeşleştirmektedirler. Bazı araştırmacılar iş yaşam kalitesinin iş performansı ile ilişkisine yönelirken, bazı çalışmalarda ise fiziksel ve ruhsal iyilik hali ile ilişkisi, iş hayatı ve topluma yabancılaşmaya olan etkisi ve işgörenlerin gelişimine olan katkısı açısından incelemişlerdir (Huzzard, 2003: 21).

İş yaşam kalitesi kavramı, içerisinde yaşam kalitesi ve iş kavramlarını içeren bir kavramdır. Yaşam kalitesi, bireylerin hedefleri doğrultusunda içerisinde bulundukları değerler sistemi içerisinde kendilerini algılama biçimi olarak tanımlanmaktadır (Gülmez, 2013). İş yaşam kalitesi, çalışanların iş ortamındaki yaşam kalitesine yönelik beklentilerine kavuşmaları şeklinde tanımlanmaktadır (Levine, vd., 1984:81). Sandhya Nair (2013: 34) iş yaşam kalitesini "çalışan ve örgütsel çevre arasındaki ilişkiler" olarak değerlendirmektedir. Cascio (1995: 23), iş yaşam kalitesi ile ilgili "işletmelerin tüm yönlerini etkisi altına alabilen inanç ve değerler zincirini oluşturan sistematik bir yaklaşım" olarak değerlendirmede bulunmuştur. Erginer (2003: 204) ise iş yaşam kalitesini, "çalışanları onurlandıran, fiziksel ve duygusal açıdan 
kendilerinin iyi hissetmelerine yardımcı olan, büyüme ve gelişme için çalışanlara imkân sağlayan bir yönetim felsefesi" şeklinde tanımlamaktadırlar. Özkalp ve Kırel (2001: 553) iş yaşam kalitesini, "çalışanların iş yaşamlarını güvenli bir ortamda sürdürebilecekleri şekilde ihtiyaçlarının karşılanması, yaptıkları iş karşılı̆̆ında işletme için faydalı oldukları duygusunun hissettirilmesi, yeteneklerini keşfetmek ve kendilerini geliştirmek için fırsatlar sunulması" şeklinde tanımlamaktadırlar. Martel ve Dupuis (2006:334) iş yaşam kalitesi değerlendirmesinde "çalışma koşullarının iyileştirilmesi, işgören memnuniyeti ve hoşnutsuzluklarının dikkate alınması, verimliliğin arttırılması, örgüt içerisinde sosyal çevrenin iyileştirilmesi, yönetim tarzının iyileştirilmesi ve iş içerisinde ve dışarısında çalışma yaşamının birbirleriyle uyum içerisinde olması" gibi unsurların iş yaşam kalitesini arttıracağını belirtmiştir.

İş yaşam kalitesi, çalışanların işyerindeki etkinliğine ve verimliliğine doğrudan etki eden bir yönetim sürecidir. İş yaşam kalitesi sürecinin yönetilmesinde; ücretlendirme ve ödül sistemi, iş güvenliği ve sağlıklı çalışma ortamı, çalışanların kendini geliştirmesi için sunulan imkânlar, işletmenin sağlıklı bir şekilde büyüme olanakları, çalışanlar arasında iletişim ve sağlıklı ilişkiler, yöneticiler ve çalışanlar arasındaki işbirliğinin sağlanması, kararlar alınırken çalışanlara danışılması ve kararlara dahil edilmesi, iş içinde ve dışında sunulan sosyal imkanlar önemli rol oynamaktadır (Walton, 1975: 93).

Bir işletmenin kârlı olabilmesi ve yaşamını uzun süre devam ettirebilmesi çalışanlarının memnuniyetiyle yakından ilişkilidir. Çalışanların memnuniyetini ölçmeyen ve arttırmak adına herhangi bir faaliyette bulunmayan işletmelerin, kısa dönemde kârlılık ve ciro artışına sahip olsalar da bu büyümeyi uzun süre devam ettirmeleri mümkün değildir. İnsan kaynakları departmanlarının işgörenler ile olan ilişkilerde verimliliği arttırma çabaları, sermaye harcamalarından ziyade beyin ve zekâ çalışmaları ile gerçekleşmektedir. Bir işletmenin başarısı, çalışanlara iyi bir iş yaşam kalitesi sağlayarak gerçekleşebilir. İş yaşam kalitesi ile çalışanlara iyi bir iş ortamı, tatmin edici ücret ve sosyal haklar, rekabetçi ve ödüllendirici bir çalışma ortamının sunulması sağlanmaktadır. Örgüt içerisinde iş yaşam kalitesini arttırmak için çalışanlara kendilerini gösterebilecekleri fırsatların sunulması gerekmektedir. Bunun sağlanabilmesi için proaktif bir yönetim anlayışı benimsenmeli ve çalışanların alınan kararlara katılımı sağlanmalıdır (Özgen vd., 2002: 307).

Walker vd., (2009:99)'a göre, iş yaşam kalitesinin üç alt boyutu bulunmaktadır. Bunlar, iş ortamı, çalışma koşulları ve sağlanan hizmetlerdir. Bu boyutları kısaca şu şekilde açılamak mümkündür:

İş Ortamı: Yapılan işin çalışanların becerilerine ve beklentilerine uygun olmasını, çalışan hedefleri ile işletme hedeflerinin uyumlu olmasını, işletme içerisinde yetki ve sorumluluğun uyumlu bir şekilde dağıtılmasını, iş dolayısıyla çalışanların toplumda gördükleri itibarı ve çalışanların işletmeden memnuniyetlerini kapsamaktadır (Walker vd., 2009: 100).

Çalışma Koşulları: Çalışma saatleri, izin uygulamaları, fiziki koşullar, iş ortamındaki sosyal aktiviteler, çalışanların gelişimleri için yapılan uygulamalar çalışma koşulları kapsamında yer almaktadır (Walker vd., 2009: 100).

Sağlanan Hizmetler: çalışanlara sağlanan yemek hizmetleri, ulaşım ve iletişim olanakları, çalışanların yararlanabileceği sosyal faaliyetler sağlanan hizmetler kapsamında değerlendirilmektedir (Walker vd., 2009: 101).

İş Performansı: Bă̆lamsal Performans ve Görev Performansı 
Performans, işgörenlerin iş yerindeki görevlerine ilişkin belirlenen kriterleri yerine getirecek şekilde faaliyetlerini tamamlaması ve işletmenin amaçlarına ulaşabilmesi için üretilen ürün, hizmet veya düşüncedir (Torrington ve Hall, 1995:316). Özbay (1996: 6)' a göre performans, "çalışanların özelliklerine ve yetenek alanlarına göre uygun olan bir işi, kabul edilebilir bir düzeyde gerçekleştirebilmesi" olarak tanımlanmaktadır. İş performansı, örgütün ulaşmak istediği hedefi gerçekleştirmek için çalışanlardan beklediği performans düzeyini ve mevcut durumda hangi düzeyde olduklarını göstermektedir (Benligiray, 2004:141). Lam ve Schaubroeck (1999: 446) iş performansını "işgörenlerin yaptıkları iş ile ilgili olan faaliyetleri başarıyla yerine getirmesi" olarak tanımlamıştır. Smith ve Goddard (2002: 250)'a göre iş performansı "miktar, zaman, nitelik ve maliyet açısından yapılan işlerin değerlendirilmesi" şeklinde ele alınmıştır. Rousseau ve McLean (1993: 43) ise iş performansı tanımında "işgörenlerin alacakları maaş karşılığında göstermeleri gereken çaba" olarak değerlendirmede bulunmuştur.

Çalışanlar sorumlu oldukları görevleri en iyi düzeyde yerine getirirken sahip oldukları bazı yeteneklerinden yararlanmakta ve gösterdiği performans neticesinde terfi ile birlikte çeşitli sosyal ve ekonomik kazançlar elde etmektedirler. Kurum çalışanları tarafından gösterilen yüksek düzeyde performans örgütü stratejik hedeflerine ulaştırmaktadır. Performansın oluşumunda; çalışanların bireysel yetenekleri, bu yetenekleri sergileme istekleri, kurumun çalışanlarına yönelik uyguladıkları politikalar çerçevesinde oluşan çalışma koşulları, çevresel faktörler ve çalışanların görev yaptığı fiziksel ortam etkili olmaktadır (Bingöl, 2014: 367).

Örgütlerin belirledikleri hedeflere ulaşabilmeleri ve bulundukları sektörde rekabet üstünlüğü elde edebilmeleri için çalışanlarının yüksek performans göstermeleri gerekmektedir (Youndt ve Snell, 2004: 339). Organizasyonların her zaman yüksek performans gösteren çalışanlara ihtiyacı vardır. Performans düzeyi, çalışanların ve organizasyonların başarılı olmasında etkili bir göstergedir (Richard vd., 2008: 720).

İş performansı, bağlamsal performans ve görev performansı olarak ikiye ayrılmaktadır. Bu kavramları kısaca şu şekilde açıklamak mümkündür (Özdevecioğlu ve Kanıgür, 2009: 59):

Bağlamsal Performans: İşgörenlerin daha fazla çalışmak için gönüllü olması, görevlerini hevesle yerine getirmesi, işbirliği içerisinde çalışmaya yatkın olması, çalıştığı kurumu sahiplenmesi ve desteklemesi, işletme içerisinde belirlenen kurallara uymasını kapsamaktadır. Bağlamsal performansta birlikte çalışılan takımın başarısı ön plandadır ve fazladan görev alma davranışı sergilenmektedir (Özdevecioğlu ve Kanıgür, 2009: 60). Bağlamsal performans, çalışma ortamındaki sosyal ve ruhsal havaya katkı sağlayan aktiviteleri kapsamaktadır. Organizasyonun verimliliği ve takım çalışmalarında başarı sağlanması önem arz etmektedir. İş ortamındaki sosyal ve motivasyonel iklime katkı sağlamak amaçlanmaktadır (Ünlü ve Yürür, 2011: 185).

Görev Performansı: Örgüt içerisinde teknik faaliyetleri yerine getirme, bu faaliyetleri yerine getirirken ihtiyaç duyulan unsurları gerçekleştirme ve çalışanların yeteneklerini kapsamaktadır. Görev performansı çalışanların uzmanlık alanları ve teknik konularla açıklanmaktadır (Özdevecioğlu ve Kanıgür, 2009: 60). Görev performansı, çalışanların iş ile ilgili aktiviteleri yerine getirmesini kapsamaktadır. İşyerinde çalışan işgörenlerin, teknik bilgi ve yeteneklerini kullanmaları görev performansı ile açıklanmaktadır (Doğan ve Özdevecioğlu, 2009: 172). 
Bağlamsal performans ve görev performansı karşılaştırıldığında, görev performansının daha çok örgütün teknik yönüne katkı sağlayarak daha iyi ürün ve hizmet üretmede destekleyici role sahip olduğunu, bağlamsal performansın ise psikolojik ortamın iyileştirilmesi, örgütsel ve sosyal ağı destekleyici etkisi olduğu söylenebilir (Vasquez-Colina, 2005: 47).

\section{Literatür Taraması ve Araştırmanın Hipotezleri}

Literatürde iş yaşam kalitesi ve iş performansı ile ilgili birçok araştırma yer almaktadır. Swathi ve Reddy (2016) öğretmenlere yönelik yaptıkları çalışmada, iş yaşam kalitesini etkileyen faktörleri araştırmışlar; ekonomik unsurların, fiziksel çalışma koşullarının, yönetim ile olan ilişkilerin, örgütsel iklimin, çalışma arkadaşları ile olan ilişkilerin ve örgütsel bağlılığın etkili olduğu sonucuna ulaşmışlardır. Hans vd. (2015), iş yaşam kalitesini etkileyen unsurlar olarak; iş ile ilgili gelişim olanakları, çalışanların tatmini, yenilikçi uygulamalar, ilgi çekici faaliyetler ve insan ilişkilerine yönelik uygulamaların etkili olduğunu tespit etmişlerdir. Kılıç ve Keklik (2012), sağlık çalışanlarında iş yaşam kalitesi ve motivasyona etkisini araştırmışlar, çalışanların iş yaşam kalitesini etkileyen en etkili faktörün maaş ve diğer ekonomik getiriler olduğu sonucuna ulaşmışlardır.

Manju (2014) yaptığı araştırmada, eğitim çalışanlarının iş yaşam kalitesinin cinsiyete göre anlamlı derecede farklılık gösterdiği, kadın çalışanlarının iş yaşam kalitesine yönelik algılarının erkeklere oranla daha yüksek olduğunu tespit etmiştir. Araştırmada iş yaşam kalitesinin yüksek düzeyde olmasında yöneticilerin önemli rol oynadıklarını belirlemiştir. Öztürk (2010: 3), hemşirelerin iş yaşam kalitesi düzeylerine yönelik yaptığı araştırmada, iş yaşam kalitesi algısının ortanın altında olduğunu tespit etmiştir. Winter vd. (2000) tarafından akademisyenlerin iş yaşam kalitesini etkileyen unsurlar üzerine araştırma yapılmış, aşırı iş yükünün, stresin, üniversite yönetiminin otoriter yaklaşımının, yüksek performans beklentisinin ve zaman yetersizliğinin iş yaşam kalitesini azalttı̆̆ sonucuna ulaşılmıştır. Dargahi vd. (2012: 251) tarafından sağlık çalışanlarına yönelik yapılan araştırmada, maaş ve ödül sisteminin yeterli olmaması, iş ortamlarının yeterince iyi olmaması, kurumda alınan kararlara çalışanların dâhil edilmemesi, iş yüklerinin fazla olması, emeklilik imkânlarının yetersiz oluşu gibi konuların iş yaşam kalitesini azaltıcı etki gösterdiği belirlenmiştir. Afşar (2011) tarafından yapılan araştırmada, aylık ücret miktarı vb. sağlanan hizmetlere yönelik yapılan iyileştirmelerin çalışanların iş yaşam kalitesi algısına katkı sağladığı sonucu ortaya çıkmıştır.

Demirok (2018), Kahya (2013), Çakıcı ve Doğan (2014), Akdemir vd. (2013) çalışmalarında iş performansı ve örgütsel sinizm arasındaki ilişkileri incelemişlerdir. Erdiren Çelebi ve Yazgan (2017), mobbing, örgütsel bağlllık ve örgütsel sinizmin iş performansı üzerindeki etkilerine yönelik çalışma yapmışlardır. Santaş vd. (2016), çalışmalarında iş performansı, örgütsel özdeşleşme ve örgütsel sinizm ilişkilerin araştırmışlardır. Takeuchi vd. (2009: 621), duygusal bağlılık ve iş performansı arasındaki ilişkiyi incelemişlerdir.

Yılmaz (2016) otel çalışanlarına yönelik yaptığı çalışmada; iş yaşam kalitesi, algılanan örgütsel destek ve iş yaşam kalitesinin iş performansı üzerindeki etkisini araştırmıştır. İş performansının iş yaşam kalitesi alt boyutları olan iş ortamı, çalışma koşulları ve sağlanan hizmetler ile pozitif yönlü ilişkili olduğunu tespit etmiştir. Gurses vd., (2009) tarafından yapılan, yoğun bakım ünitesi çalışanlarının iş yaşam kalitesi ve iş performansı arasındaki ilişkinin incelediği araştırmada, yoğum bakım üniteleri gibi ağır ve yorucu işlerde iş yaşam kalitesinin düşük olmasının çalışanların iş performanslarının gelişimine engel olduğu 
sonucuna ulaşılmıştır. Taghavi vd., (2106), öğretmenlerde iş yaşam kalitesi ve performans arasındaki ilişkiyi incelemiş ve anlamlı sonuçlar elde etmiştir. Arslan (2018) tarafından sağlık çalışanlarında iş yaşam kalitesi ve iş performansı üzerine etkisine yönelik yapılan araştırmada, iş yaşam kalitesinin iş performansı üzerinde olumlu etkisinin olduğu sonucuna ulaşılmıştır.

Tan vd., (2012) tarafından hemşirelere yönelik yapılan bir araştırmada, iş yaşam kalitesi alt boyutlarından olumlu iş ortamının iş performansını, verilen hizmetin kalitesini olumlu yönde etkilediğini tespit etmişlerdir. Hayta (2007), tarafından yapılan bir araştırmada, iş yaşam kalitesi alt boyutlarından çalışma koşullarının iş performansını ve verimliliği olumlu yönde etkilediği belirtilmiştir. Öğretmenlerin çalışma performansını etkileyen faktörlerin; takım ilişkileri, sağlıklı çalışma ortamı, meslektaşları tarafından sağlanan destek, iş tanımlarının açık bir şekilde belirlenmiş olması ve alınan kararlara katılımın olduğunu tespit etmişlerdir.

Yukarıda ilgili yazında yapılan araştırmalar incelenerek, araştırmanın amacına uygun olarak aşağıdaki hipotezler geliştirilmiştir.

Hipotez 1: İş yaşam kalitesi ve alt boyutları ile iş performansı ve alt boyutları arasında pozitif yönlü ilişki vardır.

Hipotez 2: İş yaşam kalitesi çalışanların iş performansını pozitif yönde etkilemektedir.

Hipotez 3: İş yaşam kalitesi alt boyutları iş performansı alt boyutlarından "bağlamsal performansi" pozitif yönde etkilemektedir.

Hipotez 4: İş yaşam kalitesi alt boyutları iş performansı alt boyutlarından "görev performansını" pozitif yönde etkilemektedir.

\section{Metodoloji}

\section{Araştırmanın Amacı ve Yöntemi}

Araştırmanın amacı kamu çalışanlarının iş yaşam kalitesi ile iş performansı arasındaki ilişkileri ortaya koymaktır. Ayrıca iş yaşam kalitesinin çalışanların iş performansını nasıl etkilediği de araştırmada tespit edilmek istenen konular arasında yer almaktadır. Araştırmada belirlenen amaçlara ulaşmak için alan araştırması gerçekleştirilmiştir. Alan araştırmasında veri toplama tekniği olarak anket yöntemi kullanılmıştır. Elde edilen verilerin analizinde istatistik paket programı olarak IBM SPSS 22.0 paket programı kullanılmıştır. Araştırmada çalışanların iş yaşam kalitesi ve iş performansına yönelik görüşlerini ortaya koymak için betimsel istatistik analizi uygulanmıştır. Ayrıca, araştırmanın hipotezlerini test etmek amacıyla korelâsyon analizi, basit ve çoklu regresyon analizi gerçekleştirilmiştir.

\section{Araştırmanın Örneklemi ve Veri Toplama Aracı}

Araştırma Bursa İli Karacabey ilçesine görev yapan kamu çalışanlarına yönelik gerçekleştirilmiştir. Karacabey ilçesindeki kamu çalışanlarına 200 anket formu dağıtılmış, çalışanların iş yoğunluğundan dolayı anket formlarının 158'i araştırmaya elverişli bir şekilde uygulanabilmiştir. Araştırmada kullanılan anket üç bölümden oluşmaktadır. İlk bölümde demografik özelliklere ilişkin bilgiler yer almaktadır. Anket formunun ikinci bölümünde iş yaşam kalitesine yönelik ifadeler, üçüncü bölümde ise iş performansına yönelik ifadeler yer almaktadır. 
Araştırmada, çalışanların iş yaşam kalitesine yönelik görüşlerini tespit etmek amacıyla Çiçek (2005) tarafından geliştirilen "İş Yaşam Kalitesi Ölçeği" kullanılmıştır. Ölçeğin geçerlilik ve güvenilirliği Aba (2009) tarafından test edilmiştir. Ölçek, iş ortamı, çalışma koşulları ve sağlanan hizmetler olmak üzere üç boyuttan ve 15 ifadeden oluşmaktadır. Ölçeğin orijinalinde iş ortamı boyutunda 7 ifade, çalışma koşulları boyutunda 5 ifade ve sağlanan hizmetler boyutunda 3 ifade yer almaktadır.

Araştırmada katılımcıların bağlamsal ve görev performansına yönelik ifadelerini belirlemek amacıyla Goodman ve Svyantek (1999) tarafından geliştirilen "İş Performansı" ölçeği kullanılmıştır. İş performansı ölçeğinde yer alan ifadeler Arslan (2018) tarafından Türkçe' ye çevrilmiştir. Ölçekte bağlamsal performans ve görev performansı olmak üzere iki boyut ve 25 ifade yer almaktadır. Bağlamsal performans 16 ifadeden, görev performansı ise 9 ifadeden oluşmaktadır.

Anket formunda kullanılan iş performansı ölçeğinde verilen cevaplar 5'li likert tarzında işaretlenmiştir. Ölçekte 1-Hiç katılmıyorum 5-Kesinlikle Katılıyorum şeklinde puanlanmıştır. İş yaşam kalitesini belirlemeye yönelik ifadelerde ise 1-Hiç memnun değilim, 5-Çok memnunum seçeneklerini ifade etmektedir. Araştırmada iş yaşam kalitesi ve iş performansına yönelik analizler orijinal ölçekte yer alan boyutlara göre gerçekleştirilmiştir.

\section{Araştırma Bulgularının Değerlendirilmesi}

Araştırmada elde edilen anketlerin çözümlenmesinde IBM SPSS 22.0 istatistik paket programından yararlanılmış ve hipotezlerin analizinde \%95 güven aralığı dikkate alınmıştır.

\section{Demografik Veriler}

Araştırmaya katılan işgörenlerin yaş dağılımları incelendiğinde 59 (\%37.3) kişi 25 yaş ve altı, 42 (\%26.6) kişi 26-31 yaş arası, 26 (\%16.5) kişi 32-37 yaş arası, 25 (\%15.8) kişi 38-43 yaş arası, 6 (\%3.8) kişi 44 ve üzeri yaş grubu içerisinde yer almaktadır. Katılımcıların 84 (\%53.2)' ü erkek, 74 (\%46.8)' ü kadındır. Eğitim durumları incelendiğinde, ilköğretim mezunu 53 (\%33.5) kişi, lise mezunu 38 (\%24.1) kişi, önlisans mezunu 45 (\%28.5) kişi, lisans mezunu ise 22 (\%13.9) kişi bulunmaktadır. Anket uygulamasında katılanların 87 (\%55.1)' si evli, 71 (\%44.9)' i bekârdır. Çalışanların mesleki deneyimleri incelendiğinde 1-4 yıl arası deneyime sahip olan 87 (\%55.1) kişi, 5-8 yıl deneyime sahip olan 40 (\%25.3) kişi, 9-12 yıl deneyime sahip olan 13 (\%8.2) kişi, 13 yıl ve üzeri deneyime sahip olan ise 18 (\%11.4) kişi bulunmaktadır.

\section{Güvenilirlik Analizi ve Betimsel İstatistikler}

Araştırmaya katılan kamu çalışanlarının iş yaşam kalitesine yönelik ifadelerini belirlemek için kullanılan ölçeğin güvenilirlik değeri 0.891, bağlamsal ve görev performansını belirlemeye yönelik kullanılan iş performansı ölçeğinin güvenilirlik değeri ise 0.913'tür. Cronbach's Alpha değeri $0.80 \leq \alpha \leq 1.00$ aralığında ise ölçek yüksek derecede güvenilir bir ölçektir (Kalaycl, 2008: 405). Araştırmada kullanılan her iki ölçekte yüksek derecede güvenilir bulunmuştur.

Araştırmada kullanılan ölçeklere ilişkin tanımlayıcı istatistik bilgilere aşağıdaki tablolarda yer verilmektedir.

Tablo 1: İş Yaşam Kalitesi Ölçeği Betimsel İstatistiği

\begin{tabular}{||l||c||c||c||c||c||}
\hline \hline İş Yaşam Kalitesi Ölçeği & $\mathbf{N}$ & Min. & Max. & Ort. & S.S. \\
\hline \hline İş Ortami & 158 & 1.00 & 5.00 & 3.56 & 0.71 \\
\hline
\end{tabular}




\begin{tabular}{||l||c||c|c||c|c||}
\hline Çalışma Koşulları & 158 & 1.00 & 5.00 & 3.32 & 0.97 \\
\hline \hline Sağlanan Hizmetler & 158 & 1.00 & 5.00 & 3.50 & 0.92 \\
\hline \hline İş Yaşam Kalitesi (Genel) & 158 & 1.00 & 5.00 & 3.47 & 0.74 \\
\hline
\end{tabular}

Araştırmaya katılan çalışanların iş yaşam kalitesine yönelik genel algıları ortalaması 3.47' dir. 5'li likert ölçeğinde orta değerin 3 olduğu düşünüldüğünde, çalışanların genel iş yaşam kalitesi algıları orta değerin biraz üzerindedir. İş yaşam kalitesi alt boyutlarından iş ortamı kalitesine yönelik algılama ortalaması 3.56, çalışma koşulları kalitesine yönelik algılama ortalaması 3.32, sağlanan hizmetlerin kalitesine yönelik algılama ortalaması ise 3.50' dir. En yüksek kalite algısı 3.56 ile iş ortamının kalitesine yönelik algılamadır.

Katılımcıların bağlamsal ve görev performansına yönelik görüşlerinin yer aldığ 1 iş performansı ölçeği betimsel istatistik analizi sonuçları tablo 2'de gösterilmektedir.

Tablo 2: İş Performansı Ölçeği Betimsel İstatistiği

\begin{tabular}{||l||c||c||c||c||c||}
\hline \hline İş Performansı Ölçeği & $\mathbf{N}$ & Min. & Max. & Ort. & S.S. \\
\hline \hline Bağlamsal Performans & 158 & 1.00 & 5.00 & 3.67 & 0.68 \\
\hline \hline Görev Performans1 & 158 & 1.00 & 5.00 & 3.78 & 0.68 \\
\hline \hline İş Performansı (Genel) & 158 & 1.00 & 5.00 & 3.71 & 0.65 \\
\hline \hline
\end{tabular}

Katılımcıların iş performansı ölçeğine ilişkin ifadelere katılım düzeyi genel olarak ortalama 3.71 düzeyindedir. 5'li likert sistemine göre orta değer 3 olarak kabul edildiğinde, kendi iş performanslarını ortanın üzerinde değerlendirdikleri görülmektedir. Bağlamsal performansa ilişkin ifadelere katılım düzeyleri ortalaması 3.67, görev performansı ifadelerine katılım düzeyi ortalaması ise $3.78^{\prime}$ dir. Hem bağlamsal performans hem de görev performansına yönelik katılım düzeyinin orta değerin üzerinde olduğu görülmektedir.

\section{Araştırma Hipotezlerinin Test Edilmesi}

Araştırma sonucunda elde edilen verilerin analiz yöntemine analize uygunluğuna ve analiz yöntemine karar verebilmek için, normal dağılım sergileyip sergilemediklerini belirlemek amacıyla Kolmogorov-Smirnov testi yapılmıştır. Test sonucunda Kurtosis ve Skewness değerlerinin -1 ve +1 değerleri arasında yer aldığı belirlenmiştir. Hair vd. (2013), Kurtosis ve Skewness değerleri -1 ve +1 aralığında yer aldığında normal dağılıma göre analizler yapılabileceğini ifade etmektedirler.

Hipotez 1: İş yaşam kalitesi ve alt boyutları ile iş performansı ve alt boyutları arasında pozitif yönlü ilişki vardır.

Hipotez 1'i test etmek amaciyla Pearson korelâsyon analizi gerçekleştirilmiştir. Analiz sonuçları tablo 3'de gösterilmektedir.

Tablo 3: Hipotez 1'e Yönelik Korelâsyon Analizi Tablosu

\begin{tabular}{|c|c|c|c|}
\hline & $\begin{array}{c}\text { İş Performansı } \\
\text { (Genel) }\end{array}$ & Bağlamsal Performans & $\begin{array}{c}\text { Görev } \\
\text { Performans1 }\end{array}$ \\
\hline $\begin{array}{l}\text { İş Yaşam Kalitesi } \\
\text { (Genel) }\end{array}$ & $.429^{* *}$ & $.411^{* *}$ & $.413^{* *}$ \\
\hline İş Ortamı & $.603^{* *}$ & $.579^{* *}$ & $.576^{* *}$ \\
\hline Çalışma Koşulları & $.257^{* *}$ & $.224^{* *}$ & $.285^{* *}$ \\
\hline Sağlanan Hizmetler & $.171^{* *}$ & $198^{* *}$ & .105 \\
\hline
\end{tabular}

*Korelâsyon 0.05 düzeyinde anlamlıdır

** Korelâsyon 0.01 düzeyinde anlamlıdır. 
Hipotez 1'i test etmek amaciyla gerçekleştirilen korelâsyon analizi neticesinde istatistiksel olarak anlamlı sonuçlar elde edilmiştir. İş yaşam kalitesi ile iş performansı arasında pozitif yönlü ve anlamlı 0.429 oranında ilişki olduğu tespit edilmiştir. Çalışanların iş yaşam kalitesinin arttıılması onlarım performansına olumlu katkı sağlamaktadır. İş yaşam kalitesi alt boyutlarından iş ortamı kalitesi ile bağlamsal performans arasında pozitif yönlü 0.411 oranında, görev performansında da 0.413 oranında ilişki olduğu belirlenmiştir. Çalışma koşullarının kalitesi ile bağlamsal performans arasında pozitif yönlü 0.224 oranında, görev performansı ile 0.285 oranında ilişki vardır. Sağlanan hizmetler kalitesi ile bağlamsal performans arasında pozitif yönlü 0.198 oranında ilişki olduğu belirlenmiştir. Sağlanan hizmetlerin kalitesi ile görev performansı arasında istatistiksel olarak anlamlı bir ilişki bulunamamıştır. Korelâsyon analizi genel olarak değerlendirildiğinde, iş yaşam kalitesi ile iş performansı arasında pozitif yönlü ve orta düzeyde ilişki olduğu Hipotez 1'in desteklendiği görülmektedir.

Hipotez 2: İş yaşam kalitesi çalışanların iş performansımı pozitif yönde etkilemektedir.

Katılımcıların iş yaşam kalitesine yönelik algılarının iş performansları üzerindeki etkisini tespit etmek için basit doğrusal regresyon analizi gerçekleştirilmiştir. Analiz sonuçlarına tablo $4^{\prime}$ de yer verilmektedir.

Tablo 4: Hipotez 2'ye Yönelik Basit Doğrusal Regresyon Analizi

\begin{tabular}{|l|c|c|c|c|c|c||}
\hline \hline Bağımlı Değişken: İş Performansı (Genel) \\
\hline \hline Bağımsız Değişken & $\mathbf{R}^{\mathbf{2}}$ & $\mathbf{F}$ & $\boldsymbol{\beta}$ & $\mathbf{t}$ & $\mathbf{p}$ & $\mathbf{D}-\mathbf{W}$ \\
\hline \hline$\dot{I S S ̧}_{\text {Yaşam Kalitesi (Genel) }}$ & .184 & $35.276^{* *}$ & .380 & 5.939 & $\mathbf{. 0 0 0}^{* *}$ & 1.628 \\
\hline
\end{tabular}

${ }^{*} p<0,05{ }^{* *} p<0,01$ düzeyinde anlamlidır.

Tablo 4'de yer alan basit doğrusal regresyon analizinde, bağımsız değişkenler arasında otokorelasyon olup olmadığını belirlemek amacıyla Durbin Watson test değerine bakılmış ve 1.628 olduğu tespit edilmiştir. Öztürk (2006)' ya göre Durbin Watson analizi değerinin 1.5-2.5 aralığında olması gerekmektedir. Elde edilen sonucun bu aralık içerisinde olduğu tespit edilmiştir. Çalışanların iş yaşam kalitesi algılarının iş performansı üzerindeki etkisinin incelendiği basit doğrusal regresyon analizi modelinde $R^{2}$ değerinin 0.184 olduğu belirlenmiştir. Çalışanların iş performansındaki değişikliğin 0.184 'lük kısmı iş yaşam kalitesi ile açıklanmaktadır. Beta değeri incelendiğinde iş yaşam kalitesinin iş performansı üzerinde etkili olduğunu göstermektedir. İş yaşam kalitesinde 1 birimlik artışın iş performansını 0.380 oranında arttırdığı görülmektedir. Basit doğrusal regresyon analizi neticesinde Hipotez 2'nin desteklendiği görülmektedir.

Hipotez 3: İ̧ yaşam kalitesi alt boyutları iş performansı alt boyutlarından "bağlamsal performansı" pozitif yönde etkilemektedir.

Çalışanların iş yaşam kalitesi alt boyutlarının iş performansı alt boyutlarından bağlamsal performans üzerindeki etkisini tespit etmek için çoklu regresyon analizi gerçekleştirilmiştir. Analiz sonuçları tablo 5'de gösterilmektedir.

Tablo 5: Hipotez 3'e Yönelik Çoklu Doğrusal Regresyon Analizi

Bağımlı Değişken: Bağlamsal Performans 


\begin{tabular}{|c|c|c|c|c|c|c|}
\hline $\begin{array}{l}\text { Bağımsız Değişkenler } \\
\text { (İş Yaşam Kalitesi) }\end{array}$ & $\mathbf{R}^{2}$ & $\mathbf{F}$ & $\beta$ & $\mathbf{t}$ & $\mathbf{p}$ & D-W \\
\hline$\dot{I}_{s}$ Ortamı & \multirow{3}{*}{.410} & \multirow{3}{*}{$35.734^{* *}$} & .783 & 9.684 & $.000^{* *}$ & \multirow{3}{*}{1.528} \\
\hline Çalışma Koşulları & & & -.384 & -4.344 & $.000^{* *}$ & \\
\hline Sağlanan Hizmetler & & & .210 & 2.729 & $.007^{* *}$ & \\
\hline
\end{tabular}

${ }^{*} p<0,05^{* *} p<0,01$ dïzeyinde anlamlidir.

Çoklu doğrusal regresyon analizi sonuçlarına göre, Durbin Watson test değerinin 1.528 olduğu belirlenmiş ve bağımsız değişkenler arasında otokorelasyon olmadığı tespit edilmiştir. İş yaşam kalitesi alt boyutlarının iş performansı alt boyutlarından bağlamsal performans üzerindeki etkisini inceleyen çoklu doğrusal regresyon modelinde $\mathrm{R}^{2}$ değerinin 0.410 olduğu tespit edilmiştir. Bağlamsal performanstaki değişimin 0.410 'luk kısmı iş yaşam kalitesi alt boyutları ile açıklanmaktadır. Beta değerleri incelendiğinde iş ortamı, çalışma koşulları ve sağlanan hizmetlerin bağlamsal performansı etkilediği belirlenmiştir. İş ortamı ve sağlanan hizmetler, bağlamsal performansı pozitif yönde etkilerken, çalışma koşullarının bağlamsal performans üzerinde negatif etkisi olduğu tespit edilmiştir. Çoklu doğrusal regresyon modeli ile test edilen Hipotez 3'ün desteklendiği görülmektedir.

Hipotez 4: Hipotez4: İş yaşam kalitesi alt boyutlar iş performansı alt boyutlarından "görev performansın" pozitif yönde etkilemektedir.

Katılımcıların iş yaşam kalitesi alt boyutlarına yönelik görüşlerinin görev performansı üzerindeki etkisini tespit etmek için gerçekleştirilen çoklu doğrusal regresyon analizi verilerine tablo 6 ' da yer verilmektedir.

Tablo 6: Hipotez 4'e Yönelik Çoklu Doğrusal Regresyon Analizi

\begin{tabular}{|c|c|c|c|c|c|c|}
\hline Bağımlı Değişken: Gör & rmans & & & & & \\
\hline $\begin{array}{l}\text { Bağımsız Değişkenler } \\
\text { (İş Yaşam Kalitesi) }\end{array}$ & $\mathbf{R}^{2}$ & $\mathbf{F}$ & $\beta$ & $\mathbf{t}$ & p & D-W \\
\hline Işs Ortamı & \multirow{3}{*}{.356} & \multirow{3}{*}{$28.421^{* *}$} & .637 & 7.494 & $.000^{* *}$ & \multirow{3}{*}{2.029} \\
\hline Çalışma Koşulları & & & -.032 & -.349 & .728 & \\
\hline Sağlanan Hizmetler & & & .105 & -1.293 & .198 & \\
\hline
\end{tabular}

${ }^{*} p<0,05 * * 0<0,01$ düzeyinde anlamlidir.

Tablo 6'da yer alan çoklu doğrusal regresyon modelinde, Durbin Watson test değerinin 2.029 olduğu belirlenmiş ve otokorelasyon olmaması için gereken aralık içerisinde yer aldığ 1.52.5) görüşmüştür. İş yaşam kalitesi alt boyutlarının iş performansı alt boyutlarından görev performansı üzerindeki etkisini belirlemek amacıyla gerçekleştirilen çoklu doğrusal regresyon analizi modelinde $\mathrm{R}^{2}$ değerinin 0.356 olduğu tespit edilmiştir. Görev performansındaki değişimin $0.356^{\prime} l 1 \mathrm{k}$ kısmı iş yaşam kalitesi alt boyutları ile açılanmaktadır. Beta değerleri incelendiğinde istatistiksel olarak iş ortamının anlamlı derecede görev performansını etkilediği belirlenmiştir. İş ortamı kalitesine yönelik 1 birimlik artışın görev performansını 0.637 oranında arttırdığı görülmektedir. Çoklu doğrusal regresyon modeline göre Hipotez 4'ün desteklendiği görülmektedir.

\section{Değerlendirme ve Sonuç}


$\mathrm{Bu}$ çalışma ile işgörenlerin iş yaşam kalitesine yönelik algıları ile iş performansı ve alt boyutları olan bağlamsal ve görev performansı arasındaki ilişkilerin ortaya konması amaçlanmıştır. Ayrıca iş yaşam kalitesinin, iş performansı ve alt boyutları olan bağlamsal ve görev performansı üzerindeki etkileri de araştırma ile ortaya konmaya çalışılmıştır.

Araştırma neticesinde istatistiksel olarak anlamlı sonuçlar elde edilmiştir. Katılımcıların iş yaşam kalitesine ilişkin görüşlerinin analiz edildiği betimleyici istatistik analizi gerçekleştirilmiştir. Analiz sonucunda, araştırmaya katılan çalışanların iş yaşam kalitesine ilişkin algı düzeylerinin ortanın biraz üzerinde yer aldığ görülmektedir. İş yaşam kalitesi alt boyutlarından çalışma koşullarına ilişkin memnuniyet düzeyinin diğer alt boyutlara göre daha düşük seviyede olduğu tespit edilmiştir.

Katılımcıların iş performansına yönelik görüşlerini belirlemek amacıyla yapılan betimsel istatistik analizi sonucunda, performans düzeylerini orta seviyenin üzerinde değerlendirdikleri görülmektedir. Çalışanların görev performanslarını bağlamsal performanslarından daha yüksek seviyede değerlendirdikleri tespit edilmiştir.

Araştırmaya katılan çalışanların iş yaşam kalitesi ve alt boyutları ile iş performansı ve alt boyutları arasındaki ilişkileri belirlemek amacıyla gerçekleştirilen korelâsyon analizi sonucunda pozitif yönlü ve anlamlı ilişkiler olduğu tespit edilmiştir. Çalışanların genel iş yaşam kalitesi algısı ile genel iş performansları arasında pozitif yönlü 0.429 oranında ilişki olduğu belirlenmiştir. Korelâsyon analizi sonucunda en yüksek ilişki düzeyinin genel iş performansı ile iş yaşam kalitesi alt boyutlarından iş ortamı arasında 0.63 oranında olduğu görülmektedir. Yılmaz (2016) tarafından otel çalışanlarına yönelik yapılan benzer bir araştırmada da, iş yaşam kalitesi alt boyutları olan iş ortamı, çalışma koşulları ve sağlanan hizmetler ile iş performansı arasında pozitif yönlü ilişki olduğu belirlenmiştir. Gurses vd., (2009) yoğun bakım ünitesi çalışanlarına yönelik yaptığı araştırmada, iş yaşam kalitesi düşüklüğünün sağlık çalışanlarının iş performansını düşürdüğünü tespit etmiştir.

Çalışanların iş performanslarında iş yaşam kalitesinin etkisini belirlemek amacıyla yapılan basit doğrusal regresyon modelinde anlamlı sonuçlar elde edilmiştir. Regresyon modelinde $\mathrm{R}^{2}$ değerinin 0.184 olduğu görülmektedir. Çalışanların iş performanslarının iş yaşam kalitesi ile açıklanma düzeyinin 0.184 olduğu tespit edilmiştir. İş yaşam kalitesindeki bir birimlik artışın iş performansını 0.380 oranında etkilediği belirlenmiştir. Arslan (2018) tarafından sağlık çalışanlarında iş yaşam kalitesinin iş performansı üzerine etkisine yönelik yapılan benzer bir araştırmada, iş yaşam kalitesinin iş performansı üzerinde olumlu etkisinin olduğu sonucuna ulaşılmıştır. Tan vd., (2012) tarafından hemşirelere yönelik yapılan bir araştırmada, iş yaşam kalitesi alt boyutlarından olumlu iş ortamının iş performansını pozitif yönde etkilediği tespit edilmiştir. Hayta (2007), tarafından yapılan bir araştırmada, iş yaşam kalitesi alt boyutlarından çalışma koşullarının iş performansını olumlu yönde etkilediği belirtilmiştir.

Katılımcıların bağlamsal performansa ilişkin görüşlerinde, iş yaşam kalitesi alt boyutlarının etkisini belirlemek amacıyla yapılan regresyon modelinde $\mathrm{R}^{2}$ değerinin 0.410 olduğu görülmektedir. Çalışanların bağlamsal performanslarında iş yaşam kalitesi alt boyutlarının etkisinin 0.410 olduğu tespit edilmiştir. Bağlamsal performans üzerinde en çok etkisi olan iş yaşam kalitesi alt boyutu ise iş ortamı olmuştur.

Araştırmaya katılan çalışanların görev performanslarına ilişkin görüşlerinde iş yaşam kalitesi alt boyutlarının etkisini belirlemek amacıyla kurulan çoklu doğrusal regresyon 
modelinde $\mathrm{R}^{2}$ değerinin 0.356 olduğu tespit edilmiştir. İş yaşam kalitesinin görev performansını açıklama düzeyi 0.356 'dır. Görev performansı üzerinde iş yaşam kalitesi alt boyutlarından iş ortamının istatistiksel olarak etkili olduğu, diğer alt boyutların istatistiksel olarak anlamlı bir etkisinin olmadığı belirlenmiştir.

Sonuç olarak, çalışanların iş yaşam kalitesine ilişkin algıları ile iş performanslarına yönelik görüşleri arasında pozitif yönlü ve anlamlı bir ilişki olduğu belirlenmiştir. İşletme yöneticileri çalışanların iş yaşam kalitesine yönelik iyileştirmelerde bulunduklarında, iş performanslarının da artacağı sonucu ortaya çıkmıştır. İşletmenin beşeri sermayesi olan insan kaynaklarından en yüksek düzeyde verim alınabilmesi için iş ortamının, çalışma koşullarının ve işletme tarafından sağlanan hizmetlerin personeli memnun edecek seviyede olması gerekmektedir. Aksi takdirde, nitelik olarak en iyi personele sahip olan işletmeler uygun çalışma ortamı sağlayamadıklarında çalışanlarından bekledikleri verimi elde edemeyeceklerdir. Bu çalışma neticesinde sonraki araştırmalara öneri olarak, çalışanların performanslarını etkileyen diğer unsurların tespit edilmesinin hem bilime hem de iş dünyasına katkı sağlayacağı düşünülmektedir.

\section{Kaynakça}

Aba G. (2009). İş yaşam kalitesi ve motivasyon ilişkisi: să̆lık sektöründe bir uygulama, (Yüksek Lisans Tezi), Akdeniz Üniversitesi, Antalya.

Afşar, S. T. (2011). Çalışma yaşam kalitesinin örgütsel bağlllık düzeyi üzerindeki etkisi: Devlet ve vakıf üniversitelerinde çalışan akademisyenler üzerine nicel bir araştırma. (Doktora Tezi). Hacettepe Üniversitesi, Ankara.

Akdemir, B., Kırmızıgül, B. \& Zengin, Y., (2016). Örgütsel sinizm ile iş performansı arasındaki ilişki ve bir araştırma, Kahramanmaraş Sütçü İmam Üniversitesi İ̈BF Dergisi, 6(2), 115-130.

Arslan, I. (2018), Sağlık çalışanlarında iş yaşam kalitesinin iş performansı üzerine etkisinde örgütsel desteğin aracılık rolü, (Doktora Tezi), Okan Üniversitesi, İstanbul.

Benligiray, S. (2004). İnsan kaynakları yönetimi, Anadolu Üniversitesi Yayınları. Eskişehir.

Bingöl, D. (2014). İnsan kaynakları yönetimi (Cilt 9). Beta Basım Yayım. İstanbul.

Cascio, W. F., (1995). Managing human resources, McGraw-Hill Inc. New York.

Çakıcl, A. \& Doğan, S. (2014). Örgütsel sinizmin iş performansına etkisi: meslek yüksekokullarında bir araştırma. Doğuş Üniversitesi Dergisi, 15(1), 79-89.

Çiçek, D. (2005). Örgütlerde motivasyon ve iş yaşam kalitesi: bir kamu kuruluşundaki yönetici personelin motivasyon seviyelerinin tespit edilerek iş yaşam kalitesinin geliştirilmesi üzerine bir araştırma, (Doktora Tezi), Çukurova Üniversitesi, Adana.

Dargahi, H., Changizi, V. \& Gharabagh, E. J. (2012). Radiology employees' quality of work life. Acta Medica Iranica, 50(4):250-256.

Davis, L. (1977). Enhancing the quality of work life: Developments in the United States. International Labour Review, 116, 53-65. 
Davis, L., \& Cherns, A.B. (Eds.). (1975). The quality of working life (Vol. 1). New York: Free Press.

Demirok, A. (2018). Örgütsel sinizm ve iş performansı arasındaki ilişki: Diyarbakır'da çalışan kadrolu ve sözleşmeli personel örneği, (Yüksek Lisans Tezi), Türk Hava Kurumu Üniversitesi, İstanbul.

Doğan, Y. \& Özdevecioğlu, M. (2009). Pozitif ve negatif duygusallığın çalışanların performansları üzerindeki etkisi. Selçuk Üniversitesi İ̈BF Sosyal ve Ekonomik Araştırmalar Dergisi, 12(18), 165-190.

Erdiren Çelebi, M. \&Yazgan, A.E., (2017). Mobbing, örgütsel sinizm, örgütsel bağlılık ve bunların algılanan çalışan performansı üzerine etkileri, Süleyman Demirel Üniversitesi İ.̇.B.F. Dergisi, 22(2), 267-284.

Erginer, A., 2003, İş yaşamının niteliŭi (Quality of work life), İçinde (Ed) C., Elma ve K, Demir Yönetimde Çağdaş Yaklaşımlar Uygulamalar ve Sorunlar, 2. Baskı, Anı Yayıncılık. Ankara.

Goodman, S. A. \& Svyantek, D. J. (1999). Person-organization fit and contextual performance: Do share values matter. Journal of Vocational Behavior, 55(2), 254-275.

Gurses, A. P., Carayon , P. \& Wall, M. (2009). Impact of performance obstacles on intensive care nurses" workload, perceived quality and safety of care and quality of working life. Health Services Research, 44(2), 422-443.

Gülmez H (2013). Çalışanların yaşam kalitesini etkileyen faktörler. Turkish Journal of Family Medicine and Primary Care. 7(4), 1-6

Hair, J. F., Black, W. C., Babin, B. J., Anderson, R. E. \& Tatham, R. L. (2013). Multivariate data analysis, Pearson Education. New Jersey.

Hans, A., Mobeen, S. A., Mishra, N. \& Al-Badi, A. H. (2015). A study on occupational stress and quality of work life (QWL) in Private Colleges of Oman (Muscat). Global Business and Management Research, 7(3), 55-68.

Hayta, A. B. (2007). Çalışma ortamı ve koşullarının işletme verimliliği üzerine etkisi. Ticaret ve Turizm Eğitim Fakültesi Dergisi,1, 21-41.

Huzzard, T. (2003). The convergence of the quality of working life and competitiveness. National Institute for Working Life. Stockholm

Kahya C. (2013). Örgütsel sinizm ile iş performansı arasındaki ilişki ve bir araştırma, Global Journal of Economic and Business Studies, 2(3), 34-46.

Kalayc1, Ş., (2008), SPSS uygulamalı çok değişkenli istatistik teknikleri, (3.Baskı), Asil Yayın Dağıtım. Ankara.

Kılıç, R., \& Keklik, B. (2012). Sağlık çalışanlarında iş yaşam kalitesi ve motivasyona etkisi üzerine bir araştırma. Afyon Kocatepe Üniversitesi İ̈BF Dergisi,14(2), 147-160.

Lam, S. S. \& Schaubroeck, J. (1999). Total quality management and performance appraisal: an experimental study of process versus results and group versus individual approaches, Journal of Organizational Behavior, 20(4), 445-457. 
Levine, M. F., Taylor, J. C. \& Davis, L. E. (1984). Defining quality of working life. Human Relations, 37(1), 81-104.

Manju, N. D. (2014). Quality of work life: Perception of school teachers. International Journal of Education and Psychological Research, 3(2), 77-80.

Martel J. P. \& Dupuis, G. (2006). Quality of work life: theoretical and methodological problems, and presentation of a new model and measuring instrument, Social Indicators Research, 77: 333-368.

Özbay, T. (1996). İşletmelerde performans yönetim sisteminin kullanılma amaçları ve performans yönetim sisteminde karşılaşılan sorunlar ve bir araştırma. (Yüksek Lisans Tezi), İstanbul Üniversitesi, İstanbul.

Özdevecioğlu, M. \& Kanıgür, S. (2009). Çalışanların ilişki ve görev yönelimli liderlik algılamalarının performansları üzerindeki etkileri. KMU İ̈BF Dergisi, 11, 53- 82

Özgen, H., Yalçın A. \& Öztürk, A. (2002). İnsan kaynakları yönetimi, Nobel Yayınları. Ankara.

Özkalp, E. \& Kırel, Ç. (2001). Örgütsel davranış. Anadolu Üniversitesi Yayınları. Eskişehir.

Öztürk, D. A. (2010), Hemşirelerin să̆lıklı yaşam biçimi davranışları ve iş yaşam kalitesinin iş doyum düzeyine etkileri üzerine bir araştırma, (Yüksek Lisans Tezi), Beykent Üniversitesi, İstanbul.

Öztürk, E. (2006). Çoklu Doğrusal Regresyon Modeli, Ş.Kalaycı (Ed). SPSS uygulamalı çok değişkenli istatistik teknikleri içinde. Ankara: Asil Yayın Dağıtım, 259-269.

Richard, P.J., Devinney, T.M., Yip, G.S. \& Johnson, G. (2008). Measuring organizational performance as dependent variable: Towards me thodological best practice. Journal of Management, 35(3), 718-804.

Rousseau, D. M. \& Mclean Parks, J., (1993). The contracts of individuals and organizations, Research in Organizational Behavior, 15, 1-43

Sandhya Nair, G. S. (2013). A study on the effect of quality of work life (QWL) on organisational citizenship behaviour (OCB)-with special reference to College Teachers is Thrissur District, Kerala. Integral Review: A Journal of Management, 6(1), 34-46.

Santaş, F., Uğurluoğlu, Ö., Kandemir, A. \& Çelik, Y., (2016). Sağlık çalışanlarında örgütsel sinizm, iş performansı ve örgütsel özdeşleşme düzeyleri arasındaki ilişkileri, Gazi Üniversitesi İ.I.B.F. Dergisi, 18(3), 867-886.

Smith, P. C. \& Goddard, M., (2002). Performance management and operational research: a marriage made in heaven?, Journal of The Operational Research Society, 53(3), 247-255.

Swathi, V. \& Reddy, M. (2016). Implications of stress on quality of work life among teachers : an empirical study. IPE Journal of Management, 6(1), 46-52.

Taghavi, S., Ebrahimzadeh, F., Bhramzadh, H. \& Masoumeh, H. (2016). A study of the relationship between quality of work life and performance effectiveness of high school teachers' in Shirvan. International Journal of Academic Research in Business and Social Sciences., 4(1), 295-301. 
Takeuchi, R., Wang, M., Marinova, S. V. \& Yao, X. (2009). Role of domain-specific facets of perceived organizational support during expatriation and implications for performance. Organization Science, 20(3), 621-634.

Tan, M., Polat, H. \& Şahin, Z. A. (2012).Hemşirelerin çalışma ortamlarına ilişkin algılarının değerlendirilmesi. Sağlıkta Performans ve Kalite Dergisi, 4, 67-78.

Torrinton, D. \& Hall, L. (1995). Personnel Management: HRM in Action. Prentice Hall. USA

Ünlü, O. \& Yürür, S. (2011). Duygusal emek, duygusal tükenme ve görev/bağlamsal performans ilişkisi: Yalova'da hizmet sektörü çalışanları ile bir araştırma. Erciyes Üniversitesi İktisadi ve İdari Bilimler Fakültesi Dergisi, 37, 183-207.

Vasquez-Colina, M. D. (2005). Relationships among demographic variables, organizational culture, interpersonal self-efficacy and perceived job performance. (Doctoral Dissertation), Department of Leadership, Foundations and Human Resource Development, University of Louisville, Kentucky.

Walker, B., Cheney, D. \& Stage, S. (2009). The validity and reliability of the self-assessment and program review. Journal of Positive Behavior Interventions, 11(9), 94-109.

Walton, Richard E. (1975). Criteria for quality of working life. In Davis, L.E., Cherns, A.B. and Associates (Eds.) The Quality of Working Life, New York: The Free Press,

Winter, R., Taylor, T. \& Sarros, J. (2000). Trouble at mill: Quality of academic worklife issues within a comprehensive Australian University. Studies in Higher Education, 25(3), 279-294.

Yılmaz, A. (2016), Algılanan örgütsel destek ortamında iş stresi ve iş yaşam kalitesinin iş performansı üzerine etkisinin araştırılması: İstanbul'da bulunan beş yıldızlı otellerde çalışan aş̧̧ılar üzerine bir araştırma, (Doktora Tezi), İstanbul Üniversitesi, Sosyal Bilimler Enstitüsü, İstanbul.

Youndt, M.A. \& Snell S.A. (2004). Human resource configurations, intellectual capital and organizational performance. Journal of Managerial Issues, 16(3), 337-360. 